\title{
Enzyme exposure and enzyme sensitisation in the baking industry
}

Markku Vanhanen, Timo Tuomi, Heikki Hokkanen, Outi Tupasela, Anneli Tuomainen, Peter C Holmberg, Matti Leisola, Henrik Nordman

\begin{abstract}
Objectives-To assess the exposure to enzymes and prevalence of enzyme sensitisation in the baking industry.

Methods-A cross sectional study was conducted in four bakeries, one flour mill, and one crispbread factory. Sensitisation to enzymes, flours, and storage mites was examined by skin prick and radioallergosorbent (RAST) tests. 365 workers were tested. The workers were interviewed for work related respiratory and skin symptoms. Total dust concentrations were measured by a gravimetric method, and the concentration of $\alpha$-amylase in air was measured by a catalytic method. An immunochemical method was used for measuring cellulase and xylanase in air.

Results-Total measured dust concentrations were from 0.1 to $18 \mathrm{mg} / \mathrm{m}^{3}$, with highest values in dough making areas of bakeries. The $\alpha$-amylase concentrations generally followed the total dust concentrations and reached the highest values $<6.6 \mu \mathrm{g} / \mathrm{m}^{3}$ in the same areas. Cellulase and xylanase varied with concentrations $<180 \mathrm{ng} / \mathrm{m}^{3}$ and $<40 \mathrm{ng} / \mathrm{m}^{3}$, respectively, in the flour mill and the crispbread factory. No cellulase, but concentrations of 1-200 $\mathrm{ng} / \mathrm{m}^{3}$ xylanase, were found in the bakeries, probably indicating the natural xylanase activity of wheat. 12 workers $(8 \%)$ in the bakeries, three $(5 \%)$ in the flour mill, and four (3\%) in the crispbread factory were skin prick positive to enzymes. The corresponding percentages of positive reactions to flours were $12 \%$, $5 \%$, and $8 \%$.
\end{abstract}

Occupational Health Topeliuksenkatu 41 aA, FIN-00250 Helsinki, Finland $M$ Vanhanen

T Tuomi

O Tupasela

H Nordman

Cultor Ltd,

Technology Centre, FIN-02140 Kantvik,

Finland

H Hokkanen

P C Holmberg

M Leisola

Kuopio Regional

Institute of

Occupational Health,

PO Box 93, FIN-70701

Kuopio, Finland

A Tuomainen

Correspondence to:

Dr $M$ Vanhanen, Finnish

Institute of Occupationa

Health, Topeliuksenkatu 4

aA, FIN-00250 Helsinki,

Finland.

Accepted 10 May 1996 additives in a powdered form pose a risk of sensitisation. The no effect air concentrations for industrial enzymes are not known. Based on present knowledge, however, lowering exposures and eliminating short and high peaks by technical measures would lower the risk of sensitiaccomplished by shifting to non-dusty products.

\section{(Occup Environ Med 1996;53:670-676)}

Keywords: allergy; enzymes; bakeries

Enzyme allergy in the detergent industry has been recognised since the $1960 \mathrm{~s},{ }^{12}$ and has more recently emerged in other industries. ${ }^{3-5}$ The baking industry began using enzymes in the 1970s, and their use increased rapidly in the 1980 s and 1990 s as new enzyme products were developed. Enzymes are used in dough improvers; they reduce the viscosity of dough, give the desired colouring and volume to the bread, and lengthen shelf life. The amount needed is small; the enzyme content of the improver is usually about $0 \cdot 2 \%-1 \%$, and the improver itself is only about $1 \%$ of the dough. The most commonly used enzyme is $\alpha$-amylase, but proteases and cellulases are also used. Today, most Finnish bakeries use dough improvers containing enzymes. Most of the preparations are used in powder form, being added to the dough without any specific precautions, in the same way as salt. Allergies due to enzymes in bakeries have been reported since $1986^{6-13}$ and enzymes have been proposed to be more potent sensitisers than cereal flours. ${ }^{8}$

Enzyme concentration measurements at worksites have mainly focused on protease production and its use in the detergent industry, ${ }^{14-16}$ although $\alpha$-amylases in the baking industry have also been measured..$^{817-19}$ Some protease measurements have been based on immunochemical detection methods, ${ }^{14}$ which have recently been introduced for $\alpha$-amylase as well, ${ }^{19}$ although most of the methods rely on measurements of the enzymatic activity.

Finland specifies no hygienic limit values for occupational exposure to any enzyme. The occupational limit of exposure to organic dust is $5 \mathrm{mg} / \mathrm{m}^{3}$ (eight hour average) and $10 \mathrm{mg} / \mathrm{m}^{3}$ (15 minute average).

The aim of this study was to assess the exposure to enzymes and prevalence of enzyme sensitisation in the baking industry. sation. This would be most effectively

\section{Materials and methods}

MATERIALS

The study was carried out in four bakeries, one flour mill, and a modern automated bread factory producing rye crispbread. All employees, including office personnel and lorry drivers, were invited to the tests. The participation rate was $90 \%$; it did not differ between the workplaces. Altogether, 153 employees were tested in the bakeries, 62 in the flour mill, and 150 in the crispbread factory. Table 1 shows details of the employees' age, sex, and work history. The participating bakeries in the study were typical Finnish bakeries. In all the bakeries the additives that contain enzymes were manually weighed and 
Table 1 Sex, age, atopy, smoking, and duration of employment in baking industry

\begin{tabular}{|c|c|c|c|c|c|c|c|c|c|c|c|c|}
\hline \multirow[b]{2}{*}{ Workplace } & \multicolumn{2}{|l|}{ Sex } & \multicolumn{4}{|c|}{ Age distribution (\%) } & \multicolumn{4}{|c|}{$\begin{array}{l}\text { Duration of employment in } \\
\text { baking industry (\%) }\end{array}$} & \multirow{2}{*}{$\begin{array}{l}\text { Smoking } \\
(\%)\end{array}$} & \multirow{2}{*}{$\begin{array}{l}\text { Atopy } \\
(\%)\end{array}$} \\
\hline & $M$ & $F$ & $\leqslant 30$ & $31-40$ & $41-50$ & $>50$ & $<1 y$ & $1-5 y$ & $6-10 y$ & $>10 y$ & & \\
\hline $\begin{array}{l}\text { Bakeries } \\
(n=153)\end{array}$ & 42 & 111 & 11 & 22 & 27 & 40 & 4 & 13 & 10 & 73 & 31 & 16 \\
\hline $\begin{array}{l}\text { Flour mill } \\
(n=62)\end{array}$ & 39 & 23 & 5 & 27 & 38 & 30 & 2 & 10 & 10 & 78 & 43 & 15 \\
\hline $\begin{array}{l}\text { Crispbread } \\
\text { factory } \\
(n=150)\end{array}$ & 78 & 72 & 9 & 15 & 46 & 29 & 1 & 9 & 11 & 79 & 31 & 25 \\
\hline
\end{tabular}

added to the dough, along with other additives such as sugar, salt, and spices. Local exhaust ventilation in flour pouring was used only in one bakery, and respiratory protective devices were seldom worn. The enzyme in the baking additive was $\alpha$-amylase of fungal origin (Aspergillus oryzae), and comprised $0.3 \%$ of the total weight. In the flour mill, mixtures of flour and additives for bakery use were produced in the same department and packed in $20 \mathrm{~kg}$ sacks for delivery. The enzyme additive was a mixture of cellulase, $\alpha$-amylase, and xylanase, and the flours were wheat and rye. The enzyme additive mixtures were premixed in the flour mill's laboratory, where the handling took place in a flow cabinet. The mixtures were packed in lots weighing $1-3 \mathrm{~kg}$; the work was relatively dusty, and the mixture often spilt onto the packing tables. In the crispbread factory the enzyme was added automatically to the continuously working dough machines, where operators could become exposed. Cellulase was mainly used here, but to a lesser extent $\alpha$-amylase and protease. The cellulase content of the dough here was less than one tenth of that of $\alpha$-amylase in the bakeries.

\section{METHODS}

\section{Questionnaire}

The employees answered a questionnaire on work history, history of atopy, smoking habits, and work related symptoms indicating hypersensitivity. The questionnaire was a modification of sets of questionnaires that have been used in several epidemiological studies concerning work related allergies in Finland.

Skin prick tests

To find atopic status, common environmental inhalant allergens were used: cat, dog, timothy, birch, alder, mugwort, and house dust mite (Dermatophagoides pteronyssinus), Aspergillus fumigatus, Alternaria alternata, Cladosporium, and Penicillium (Allergologisk Laboratorium A/S, ALK, Copenhagen, Denmark). Histamine hydrochloride $(10 \mathrm{mg} /$ $\mathrm{ml}$ ) was used as the positive control. A person with one or more positive skin prick test reactions to environmental allergens was defined as atopic.

Wheat, rye, oat, and barley flours were prepared specially for the skin prick tests. The source materials for these preparations were blends of flours from five to eight different producers. Flour extracts were made according to the modification of Björksten et al. ${ }^{20}$ Briefly, $30 \%(w / v)$ flour mixtures were made in $0.05 \mathrm{M}$ sodium acetate buffer, $\mathrm{pH} 3.8$, mixed for one hour at room temperature, and centrifuged (27 $000 \mathrm{~g}$ for 50 minutes). Supernatants were designated as acid fractions. To obtain the neutral fractions, the remaining flour centrifugate was extracted again with an equal amount of phosphate buffered saline $(0.01 \mathrm{M}$ potassium phosphate, $0.4 \mathrm{M} \mathrm{NaCl}$, $\mathrm{pH} 7 \cdot 0$ ), mixed for two hours at room temperature, and centrifuged as already described. The acid and neutral flour fractions were concentrated by ultrafiltration, mixed, and lyophilised. For prick testing, the lyophilised flour extracts were diluted in albumin diluent (Pharmacia, Uppsala, Sweden) to achieve a flour protein content of $1 \mathrm{mg} / \mathrm{ml}$.

As test enzymes, commercial enzyme preparations were used: bacterial $\alpha$-amylase (BAN 1000 S, Novo Nordisk A/S, Denmark), fungal $\alpha$-amylase (Sal Conc, Shin Nihhon, Japan), bacterial protease (Neutrase, Novo Nordisk $\mathrm{A} / \mathrm{S}$ ), fungal protease (Veron AP, Röhm $\mathrm{GmbH}$, Germany), fungal glucose oxidase (Oxygo M 500, Genencor International, Finland), fungal cellulase (Multifect CS, Genencor International) and fungal xylanase (Xylanase 250, Ueda Chemical Industrial, Japan). Dry commercial enzyme preparations were extracted in $0.1 \mathrm{M}$ potassium phosphate buffer, $\mathrm{pH} 7 \cdot 4$, and diluted to the Coca solution $(0.5 \% \mathrm{NaCl}, 0.3 \%$ sodium bicarbonate, $0.4 \%$ phenol) to achieve a protein concentration of $100 \mu \mathrm{g} / \mathrm{ml}$. A part of this solution $(2.5 \mathrm{ml})$ was passed through a Millex-GV filter $(0.22 \mu \mathrm{m}$ membrane, Millipore) into a sterile vial containing $2.5 \mathrm{ml}$ glycerol, to yield a final protein concentration of $50 \mu \mathrm{g} / \mathrm{ml}$. The Cocaglycerol solution served as a negative control. Prick tests with these enzyme extracts were negative in a group of 15 non-exposed people.

For the storage mite tests, Acarus siro, Lepidoglyphus destruens, and Tyrophagus putres (ALK, Copenhagen) were used.

The skin prick tests were performed and the results scored routinely. ${ }^{21}$ The test was done on the volar aspect of the forearm. The result was read as the mean of the longest diameter of the weal and the diameter perpendicular to it. A weal of $\geqslant 3 \mathrm{~mm}$ diameter and equal to or greater than half of that of the histamine was defined as positive, indicating sensitisation.

\section{IgE measurements}

Specific IgE antibodies to enzymes were measured by a radioallergosorbent test (RAST). Proteins of commercial enzyme preparations were conjugated to cyanogen bromide activated paper discs by the method of Ceska et 
al. 22 Other reagents for RAST were obtained from the Phadebas RAST kits (Pharmacia Diagnostics, Sweden). The results, in $\mathrm{kU} / \mathrm{l}$, were based on the RAST reference serum (Pharmacia Diagnostics). Values $>0.35 \mathrm{kU} / 1$ were defined as positive, indicating sensitisation.

\section{Enzyme and total dust measurement}

There are only a few publications on air concentrations of enzymes in the baking industry. ${ }^{23}$ We wanted to make measurements to estimate the concentrations of the three main enzymes and to describe the exposures in different phases of the processes. Air samples for measuring the total dust and enzyme activities were taken during one shift in three bakeries, in the flour mill, and in the crispbread factory. Due to the resources available for hygienic measurements only a few samples could be taken and analysed. In bakeries, all work phases from making the dough to packing the products were examined with emphasis on making the dough and the bread. In the flour mill, only the area for mixing the additives and the laboratory nearby were sampled. In the crispbread factory, samples were taken in all the production areas before roasting. Due to the continuous nature of the process the dust concentrations were expected to be even in the baking area and stationary sampling was mainly applied. A group of workers in one shift wore the personal sampling pumps and stationary samples were taken during the shift. The sampling time varied from one to two hours with the static samples and from two to four hours with the personal samples. The consecutive personal samples were taken to cover the whole working shift. The samples for total dust and $\alpha$-amylase measurement were taken by a standardised method in the breathing zone of the workers at a flow rate of $2 \mathrm{l} / \mathrm{min}$ and by stationary sampling at a flow rate of 20 $1 / \mathrm{min}$, with $37 \mathrm{~mm}$ Millipore AA filters in an open face Millipore cassette for gravimetric measurement of the dust. The detection limit of this method is $0.1 \mathrm{mg} / \mathrm{m}^{3}$ for total dust. High volume sampling (GMW Handi-Vol 2000) at a flow rate of $25 \mathrm{~m}^{3} / \mathrm{h}$ and glass fibre filters (Whatman $\mathrm{GF} / \mathrm{C}$ ) were used for collecting the cellulase and xylanase enzymes.

$\alpha$-Amylase was analysed colorimetrically with a commercial standard kit (Merckotest). ${ }^{17}$ The method gives the amount of active enzyme. The standard curves were obtained from enzymes identical to those used at worksites where the samples were collected. ${ }^{17}$ The detection limit, which depends on sample volume, was $0 \cdot 1 \mu \mathrm{g} / \mathrm{sample}$.

The cellulase and xylanase contents of the samples were measured by a method based on antibodies, with the dot blot technique. ${ }^{21}$ Cellobiohydrolase I (CBH I), which accounts for $60 \%-80 \%$ of the cellulase complex of Trichoderma reesei, ${ }^{2 i}$ and xylanase pI $9 \cdot 0$, one of the two major xylanases produced by Trichoderma reesei, ${ }^{20}$ were measured, and thus served as indicatory enzymes for the cellulase and xylanase complexes in air.

Sample filters were placed in $20 \mathrm{ml}$ of extracting buffer $(0.05 \mathrm{M}$ sodium acetate, $0 \cdot 2 \%$ ammonium sulphate, $0.01 \%$ Triton $\mathrm{X}$, $\mathrm{pH} 4 \cdot 8$ ) and were incubated at $4^{\circ} \mathrm{C}$ overnight. The extract was homogenised (Janke and Kunkel homogeniser) and filtered with a Millipore AP 15 filter. Of the filtered sample $1 \mathrm{ml}$ was lyophilised and dissolved in a solution which consisted of $50 \mu \mathrm{l}$ of the extracting buffer and $50 \mu \mathrm{l}$ of the denaturing buffer $(5 \%$ SDS, $10 \% \beta$-mercaptoethanol, $0.01 \mathrm{M}$ TRIS, $0.001 \mathrm{M}$ EDTA, pH 8.0). The samples were then denatured in a boiling water bath for five minutes and diluted in the denaturing buffer in the ratios of $1: 10,1: 100,1: 1000$, and 1:10 000. The CBH I and xylanase pI 9.0 enzyme proteins were used as standards and diluted correspondingly in the same buffers. The sample and standards were pipetted, $100 \mu \mathrm{l} / \mathrm{dot}$, on to a nitrocellulose sheet (Schleicher and Schuell BA 85, 0.45 $\mu \mathrm{m}$ ) pretreated with TBS $(0 \cdot 01 \mathrm{M}$ TRIS-HCl, $0 \cdot 15 \mathrm{M}$ $\mathrm{NaCl}, \mathrm{pH} 8 \cdot 0)$ for 15 minutes, with a filtration manifold (Minifold I SRC 96 D, Schleicher and Schuell). The sheet was dried on a filter paper and blocked with $1 \%$ bovine serum albumin in TBST (TBS with $0.05 \%$ Tween 20) for 30 minutes at room temperature. It was then incubated at room temperature for one hour with monoclonal antibody to CBH I or antibody to xylanase pI $9 \cdot 0$ (prepared in rabbits by Dr Kubicek, Institut für Biochemische Technologie und Mikrobiologie, Vienna, Austria). The sheet was then washed with TBST three times, incubated with antibody to rabbit IgG conjugated to alkaline phosphatase (Sigma A-8025) for one hour, and washed again with TBST thrice. The bound alkaline phosphatase on the sheet was detected by a substrate (5-bromine4-chlorine-3-indolphosphate, BCIP; Promega) and a staining reagent (nitro blue tetrazolium, NBT; Promega). Sixty microlitres of $0.06 \mathrm{M}$ NBT and $33 \mu \mathrm{l} 0 \cdot 13 \mathrm{M}$ BCIP in $10 \mathrm{ml}$ substrate buffer $(0 \cdot 1 \mathrm{M}$ TRIS, $0 \cdot 1 \mathrm{M} \mathrm{NaCl}, 0 \cdot 005$ $\mathrm{M} \mathrm{MgCl}_{2}$, pH 9.5) were used. The sheet was washed with water and dried in air. The intensities of the colour of the sample dots were compared with those of the standard dots. The detection limits were $20 \mathrm{ng} / \mathrm{m}^{3}$ for CBH I and $2 \mathrm{ng} / \mathrm{m}^{3}$ for xylanase $\mathrm{pI} 9 \cdot 0$.

In statistical analyses a value of half of the detection limit was assigned to samples under the detection limit.

\section{Results}

AIR CONCENTRATIONS OF TOTAL DUST AND ENZYMES

Table 2 shows the results of the measurements at the workplaces. In the three bakeries the mean total dust concentration in the breathing zone exceeded the occupational exposure limit during dough making. In the largest bakery, local exhaust ventilation was used in the flour pouring area, and the total dust concentration was $3-5 \mathrm{mg} / \mathrm{m}^{3}$ in the breathing zone of the dough maker, whereas in the other two bakeries the corresponding values were around $10 \mathrm{mg} / \mathrm{m}^{3}$. In other bread making activities the dust concentrations were generally lower, and 
Table 2 Mean range concentrations of total dust and the enzymes $\alpha$-amylase, cellulase, and xylanase in workplace air

\begin{tabular}{|c|c|c|c|c|c|c|}
\hline & $n$ & $\begin{array}{l}\text { Total dust } \\
\left(\mathrm{mg} / \mathrm{m}^{3}\right)\end{array}$ & $\begin{array}{l}\alpha \text {-Amylase } \\
\left(\mu g / m^{3}\right)\end{array}$ & $n$ & $\begin{array}{l}\text { Cellulase, } \\
\text { CBH 1 } \\
\left(n g / m^{3}\right)\end{array}$ & $\begin{array}{l}\text { Xylanase, } \\
\text { pI } 9.0 \\
\left(\mathrm{ng} / \mathrm{m}^{3}\right)\end{array}$ \\
\hline \multicolumn{7}{|l|}{ Bakeries: } \\
\hline Breathing zone & 7 & $8 \cdot 4(3 \cdot 0-18 \cdot 8)$ & $2 \cdot 3(<0.2-6.6)$ & - & - & - \\
\hline Stationary samples & 9 & $2 \cdot 5(0 \cdot 7-8 \cdot 4)$ & $1.5(0.04-4.3)$ & 8 & $<\mathrm{dl}$ & $65(2-200)$ \\
\hline \multicolumn{7}{|l|}{ Bread making: } \\
\hline Breathing zone & 10 & $3 \cdot 2(1 \cdot 2-5 \cdot 5)$ & $0.1(<0.4)$ & - & - & - \\
\hline $\begin{array}{l}\text { Stationary samples } \\
\text { Packing: }\end{array}$ & 11 & $1 \cdot 1(0 \cdot 1-2 \cdot 9)$ & $0.3(<0.02-2 \cdot 0)$ & 1 & $<\mathrm{dl}$ & 2 \\
\hline Stationary samples & 1 & $0 \cdot 1$ & $<0.01$ & 1 & $<\mathrm{dl}$ & 2 \\
\hline \multicolumn{7}{|l|}{$\begin{array}{l}\text { Flour mill: } \\
\text { Mixing: }\end{array}$} \\
\hline Breathing zone & 2 & $5(3 \cdot 3-6 \cdot 7)$ & $0.9(0.7-1 \cdot 1)$ & - & - & - \\
\hline Stationary samples & 4 & $1 \cdot 0(0 \cdot 7-1 \cdot 3)$ & $0.07(<0.02-0.2)$ & 3 & $110(65-180)$ & $3(2-5)$ \\
\hline \multicolumn{7}{|l|}{ Laboratory: } \\
\hline Breathing zone & 1 & 1.8 & $<0.6$ & - & - & - \\
\hline Stationary samples & 1 & 0.3 & $<0.07$ & - & - & - \\
\hline \multicolumn{7}{|l|}{ Crispbread factory: } \\
\hline Breathing zone & 10 & $3 \cdot 1(1 \cdot 0-9 \cdot 4)$ & $0.1(0.7)$ & - & - & - \\
\hline Stationary samples & 6 & $0 \cdot 8(0 \cdot 2-2 \cdot 1)$ & $0.03(<0.02-0.09)$ & 4 & $85(25-160)$ & $22(7-40)$ \\
\hline
\end{tabular}

$\mathrm{dl}=$ Detection limit

only occasionally higher than $5 \mathrm{mg} / \mathrm{m}^{3}$. The total dust concentration of $5 \mathrm{mg} / \mathrm{m}^{3}$ was exceeded in five personal samples in the dough making and in baking areas. In general, the concentrations were higher in the breathing zone than at the stationary sampling sites. The concentration data have a normal distribution.

The $\alpha$-amylase concentrations followed the total dust concentrations. The concentrations in the breathing zone generally were $<0.2 \mu \mathrm{g} / \mathrm{m}^{3}-6.6 \mu \mathrm{g} / \mathrm{m}^{3}$ in dough making, and were $<0.2 \mu \mathrm{g} / \mathrm{m}^{3}$ in bread making, although in some dusty phases of bread making the $\alpha$ amylase concentration exceeded that in the breathing zone. The relative concentration of $\alpha$-amylase seemed to be higher in dough making where bread improvers were added, compared with other locations in the bakery where

Table 3 Positive skin prick tests to enzymes, flours, storage mites, and environmental allergens

\begin{tabular}{llllll}
\hline \multicolumn{5}{l}{ Positive skin prick tests $(n(\%))$} \\
\cline { 2 - 6 } Workplaces & $\begin{array}{l}\text { People } \\
\text { tested }(n)\end{array}$ & Enzymes & Flours & $\begin{array}{l}\text { Storage } \\
\text { mites }\end{array}$ & Atopy \\
\hline Bakeries & 153 & $12(8)^{\star}$ & $19(12)$ & $14(9)$ & $25(16)$ \\
Flour mill & 62 & $3(5) \dagger$ & $4(6)$ & $6(10)$ & $9(15)$ \\
Crispbread factory & 150 & $4(3) \ddagger$ & $12(8)$ & $19(12)$ & $37(25)$ \\
Total & 365 & $19(5)$ & $35(10)$ & $39(11)$ & $71(19)$ \\
\hline
\end{tabular}

^Fungal $\alpha$-amylase, fungal protease.

†Fungal $\alpha$-amylase.

$\ddagger$ Cellulase, glucose oxidase.

Table 4 Distribution of positive enzyme reactions by skin prick test (SPT) and radioallergosorbent test ( $R A S T)$

\begin{tabular}{|c|c|c|c|c|c|}
\hline \multirow[b]{2}{*}{$\begin{array}{l}\text { Workplaces } \\
\text { (people tested) }\end{array}$} & \multirow[b]{2}{*}{$\begin{array}{l}\text { Positive skin } \\
\text { prick test to } \\
\text { enzymes } \\
(n(\%))\end{array}$} & \multicolumn{4}{|l|}{ Enzyme } \\
\hline & & $\begin{array}{l}\text { Fungal } \\
\alpha \text {-amylase } \\
\text { SPT/RAST }\end{array}$ & $\begin{array}{l}\text { Fungal } \\
\text { protease } \\
S P T / R A S T^{*}\end{array}$ & $\begin{array}{l}\text { Cellulase } \\
\text { SPT/RAST }\end{array}$ & $\begin{array}{l}\text { Glucose } \\
\text { oxidase } \\
\text { SPT/RAST* }\end{array}$ \\
\hline Bakeries $(n=153)$ & $12(8)$ & $12 / 5$ & $3 / 0$ & $0 / 0$ & $0 / 0$ \\
\hline Flour mill $(n=62)$ & $3(5)$ & $3 / 2$ & $0 / 0$ & $0 / 0$ & $0 / 0$ \\
\hline $\begin{array}{l}\text { Crispbread } \\
\text { factory }(n=150)\end{array}$ & $4(3)$ & $0 / 0$ & $0 / 0$ & $3 / 0$ & $1 / 0$ \\
\hline
\end{tabular}

^All people who were RAST positive were also SPT positive.

Table 5 Number of people sensitised to flours and enzymes (skin prick test positive) in different jobs at the bakeries

\begin{tabular}{llll}
\hline fob & Enzyme only & Enzyme + Flour & Flour only \\
\hline Bakers $(\mathrm{n}=76)$ & 4 & 5 & 8 \\
Packers $(\mathrm{n}=55)$ & 1 & 2 & 3 \\
Others $(\mathrm{n}=22)$ & & 1 \\
\hline
\end{tabular}

Others = Management and office personnel, lorry driver. the flours were handled without additives. All the cellulase measurements indicated concentrations below the detection limit, but the xylanase concentrations varied widely.

Only a few measurements could be made in the flour mill during the actual mixing of the special flour products, due to current technical problems in production. However, in full activity the flour dust concentration exceeded the occupational exposure limit, and the $\alpha$ amylase concentration was comparable with that during dough making in the bakeries. In the laboratory, the total dust concentration in the breathing zone sample was clearly higher than that in the stationary sample collected about one metre from the breathing zone of the laboratory technician. The concentration of cellulase was $65-180 \mathrm{ng} / \mathrm{m}^{3}$ at the site where additives were mixed, and was highest during active mixing.

In the crispbread factory, the total dust concentrations in the breathing zone of the workers who control and adjust the automatic bread forming line were $2-3 \mathrm{mg} / \mathrm{m}^{3}$, and generally less in departments where dough making and additive mixing took place. Comparable concentrations of cellulase were measured in different phases of mixing, dough making, and bread forming as in the additive mixing in the flour mill. The concentrations of xylanase, however, were higher in the crispbread factory.

\section{SENSITISATION TO ENZYMES, FLOURS, AND} STORAGE MITES

Tables 3-5 summarise the results. In the bakeries, $19(12 \%)$ out of 153 people were sensitised to flours and $12(8 \%)$ to enzymes, five of whom reacted only to enzymes and seven to both flours and enzymes. Five of the 12 workers positive to the enzyme prick tests also had positive RASTs. The enzyme reactions in skin prick tests were all to fungal $\alpha$-amylase, and three people who reacted to $\alpha$-amylase also reacted to fungal protease. Table 5 summarises the distribution of the prick test reactions to enzymes and flours in the main groups of workers in the bakeries. As expected, most of the sensitisation was among the bakers, who are the most exposed group. None of the sensitised packers had previously worked as a baker. Fourteen ( $9 \%$ ) people had positive 
prick test reactions to storage mites.

In the flour mill, three (5\%) people out of 62 were sensitised to enzymes and four to flours; one of these reacted to both. Three workers with a positive skin prick test had a positive RAST test to flour and two were positive to enzyme. The enzyme reactions were to fungal $\alpha$-amylase. Six (10\%) had positive reactions to storage mites.

In the crispbread factory, $12(8 \%)$ people out of 150 were sensitised to flours and four (3\%) to enzymes; two of these reacted to both flours and enzyme. Of those positive to the flour prick, eight had positive RASTs. Three of the enzyme reactions were to cellulase, one was to glucose oxidase. Enzyme RASTs were negative. Nineteen (12\%) workers had positive prick tests to storage mites.

There were nine people sensitised to enzymes but not to flours, and four only to enzymes, without reactions to any other allergen tested.

\section{ATOPY AND SMOKING}

of all the workers in the bakeries, flour mill, and crispbread factory, $16 \%, 15 \%$, and $25 \%$, respectively, were atopic. By comparison, 18 $(51 \%)$ of all the 35 workers who reacted to flours were atopic. Of these 35 workers positive to flours, nine $(26 \%)$ reacted to timothy, and four to mugwort. Nine $(47 \%)$ of the 19 who reacted to enzymes were atopic. Of all those 321 who were not sensitised to flours or enzymes, $51(16 \%)$ were atopic.

In the bakeries, 47 people (31\%) were smokers, in the flour mill $26(43 \%)$, and in the crispbread factory $47(31 \%)$. Of all the 46 people with positive prick tests to flours or enzymes, $14(30 \%)$ were smokers. Of all those 321 not sensitised to flours or enzymes, 122 $(38 \%)$ were smokers.

\section{SYMPTOMS AT WORK}

Twenty one $(14 \%)$ of the workers in the bakeries, $11(18 \%)$ in the flour mill, and $25(17 \%)$ in the crispbread factory reported having symptoms at work; almost all of them (85\%) had rhinitis (sneezing, runny, or stuffy nose). Cough or dyspnoea was reported by $5 \%$ in the bakeries and $3 \%$ in the crispbread factory. Correspondingly, itching of the eyes or skin (face, arms) was reported by $4 \%$ and $3 \%$. Of all the 46 people with a positive prick test reaction to flours or enzymes, 27 (59\%) had symptoms. Of these 27,20 were sensitised only to flours, six to both flours and enzymes, and one only to enzymes. Six (22\%) of these were also

Table 6 Symptoms at work: positive test reactions in symptomatic workers

\begin{tabular}{lllllll}
\hline & & \multicolumn{4}{c}{ Positive skin prick test, workers with work related symptoms $(n(\%))$} \\
\cline { 3 - 7 } Workplace & Total & Flours & Enzymes & $\begin{array}{l}\text { Storage } \\
\text { mites }\end{array}$ & Atopy & \multicolumn{1}{l}{$\begin{array}{l}\text { Tests } \\
\text { negative }\end{array}$} \\
\hline Bakeries & 21 & $11(52)$ & $5(24)^{\star}$ & $6(29)$ & $7(33)$ & $6(29)$ \\
Flour mill & 11 & $3(27)$ & $1(10)^{\dagger}$ & $1(10)$ & $3(27)$ & $6(55)$ \\
$\begin{array}{l}\text { Crispbread } \\
\text { factory }\end{array}$ & 25 & $6(24)$ & $2(8) \ddagger$ & $3(12)$ & $11(44)$ & $11(44)$ \\
Total & 57 & $20(35)$ & $8(14)$ & $10(18)$ & $21(37)$ & $23(40)$ \\
\hline
\end{tabular}

$\star$ Fungal $\alpha$-amylase, fungal protease.

tFungal $\alpha$-amylase.

†Cellulase. smokers. Table 6 summarises the results and the association of the symptoms with the skin prick test findings.

Seven out of nine people sensitised to enzymes but not to flours had work related symptoms. One out of four people sensitised to enzymes but not to any other allergen tested had work related symptoms.

\section{Discussion}

The use of microbial enzymes in bakeries has become common throughout Europe, and most bakeries in Finland use them. Although $\alpha$-amylase is the most common, proteases, cellulases, and glucose oxidase are on the increase. Enzyme use varies according to the type of producer: bread bakeries use $\alpha$-amylases, but those producing biscuits, crackers, and crispbread primarily use proteases and cellulases. As the industrial grades of enzymes are poorly purified, they contain varying amounts of other enzymes produced by the micro-organism in question. Thus $\alpha$-amylase, for example, may contain proteases, and cellulases xylanases, and vice versa. This may cause unexpected sensitisations and cross reactions, as became apparent in our skin prick tests: some workers exposed to $\alpha$-amylase reacted to fungal proteases as well as $\alpha$-amylases.

The total dust concentrations often showed concentrations in excess of the hygienic limit values. $\alpha$-Amylase concentrations were particularly high ( $\leqslant 6.6 \mu \mathrm{g} / \mathrm{m}^{3}$ during dough making). The difficulties in controlling dust exposure in bakeries have been discussed earlier. ${ }^{172728}$ Flour, especially wheat, contains natural $\alpha$-amylase. ${ }^{29}$ The extent to which the measured $\alpha$-amylase in air was due to the natural enzyme content of flours could not be assessed with the analytical technique used in the present study.

The method used to measure $\alpha$-amylase detects only the active enzyme. The cellulase and xylanase methods detect inactive enzyme as well. As there is no reason to expect the allergenic activity to be linked to enzymatic activity, the immunochemical method should therefore be more accurate in assessing the sensitising property of the dust. However, parallel measurements with both methods are needed to confirm this assumption. We used a new immunochemical method for measuring cellulase and xylanase. This method detects the protein which carries the allergenic properties, thus giving a more accurate and better defined estimate of the allergenic enzyme dust in air. The detection limit for both enzymes was very low when large volumes were sampled. The immunochemical method is relatively easy and simple to conduct, but the preparation of antibodies is costly. In the present study we used semiquantitative analysis by visual comparison of the sample dots with the standards, but in the next phase of the study photometric reading will be used.

We have not seen any earlier reports on air measurements of cellulase in bakeries. We detected cellulase in the air of the flour mill and the crispbread factory, but not in the bak- 
eries. Cellulase was used as an additive in the flour mill and in the crispbread factory, but not in the bakeries. Thus the cellulase in air seems to reflect the added enzyme rather than the natural content of flours. This assumption was supported by an experiment in which rye flour containing added cellulase at a concentration corresponding to the normal value, and the same flour without added enzyme, were made into aerosols in a $10 \mathrm{~m}^{3}$ dust chamber. A concentration of $10 \mu \mathrm{g} / \mathrm{m}^{3}$ of cellulase was measured with added cellulase at a total dust concentration of $10 \mathrm{mg} / \mathrm{m}^{3}$, but without added enzyme the cellulase concentration remained $<70 \mathrm{ng} / \mathrm{m}^{3}$ (30 minute sampling time) at a total dust concentration of $30 \mathrm{mg} / \mathrm{m}^{3}$.

Xylanase was detected in the air of the bakeries although it was not added to the flour. However, our measurements showed that wheat flour itself contains small amounts of natural xylanase.

Sensitisation to enzymes in the bakeries was found in $8 \%$ of the 153 tested workers. This rate was similar to those reported in Italian ${ }^{12}$ and in United Kingdom bakeries, ${ }^{13}$ but lower than in Germany. ${ }^{7}$ A high rate $(30 \%)$ has also been found in a Swedish factory producing baking additives. ${ }^{8}$ These discrepancies probably reflect the exposure intensities or exposure times. Our skin prick test solution was milder than the one in the Swedish study, but it is difficult to estimate whether this could lead to differences in sensitisation rates.

In bakeries the sensitisation was caused by fungal $\alpha$-amylase, which was the enzyme used in the additives; no reactions were found to bacterial $\alpha$-amylase. This finding suggests that fungal and bacterial $\alpha$-amylase have different antigenic characteristics, which was confirmed by immunoblotting and RAST inhibition. The finding that some of the $\alpha$-amylase positive workers reacted to fungal protease may have been due to cross reactivity because of the same production microbe.

The question of whether the natural enzyme content of grain is significant in sensitisation has been posed. Sandiford et $a l^{29}$ showed cereal $\alpha$-amylases to be important allergens in patients with allergy to flour, whereas only minimal cross reactivity was found between cereal $\alpha$-amylases and fungal $\alpha$-amylase. We cannot exclude the possibility that some of the enzyme positive reactions might be due to inherent flour enzyme. However, some results indicate that the added enzyme was mainly responsible for the reactions. The $\alpha$-amylase and cellulase reactions were found in workplaces where each of these enzymes were used. There were also several reactions to enzymes without simultaneous sensitisation to flours.

The possible role of sensitivity to fungi as an explanation of enzyme reactions has been discussed. Quirce et $a l^{11}$ found some degree of cross reactivity between Aspergillus oryzae and $\alpha$-amylase, and between cellulase and Aspergillus niger. Moneo et $a l^{30}$ recently reported on millers sensitised to fungal $\alpha$-amylase, although not exposed to enzyme, and suggested that the sensitisation was due to contamination of the grain or flour by
Aspergillus and other moulds. In our study, only a few reactions to moulds were found, and not in the people reacting to enzymes.

Sensitisation to flours was most frequent $(8 \%)$ in the bakeries, and similar rates have been reported by others. ${ }^{12} 31$ In a recent report from the United Kingdom, 5\% of a cohort of 264 workers in bakeries and mills were sensitised to flours. ${ }^{13}$

Reactions to storage mites were also common (up to $12 \%$ ). The results are in agreement with previous reports ${ }^{132732}$ showing storage mite sensitisation to be common in farmers and bakers. Most of the people positive to storage mites also reacted to house dust mites. Storage mites and house dust mites have been shown to cross react in allergy tests, but most of the allergenic determinants are species specific. ${ }^{33}$

As in earlier reports, ${ }^{6122731}$ atopy was overrepresented among those sensitised to flour (51\%) and enzymes (47\%). This should not, however, be construed as a justification for excluding workers at recruitment because of atopy ${ }^{1234}$; the predictive value of atopy is far too low to justify such a practice. Smoking was equally common among the sensitised and non-sensitised workers. Assessment of the cause of the employees' symptoms from the data collected is difficult because of the common overlapping of sensitisation to different allergens.

Our study population represents a survivor population. No records were available about the leavers, nor was the exact turnover rate known. All the workplaces were situated in small towns with little chance to change jobs. Consequently, the duration of employment was long and the turnover rather low. Sensitisation at work is generally thought to take place within the first years of exposure. This could not be estimated with this study design.

The use of enzymes in the baking industry is likely to continue and increase. Several studies apart from ours have shown that industrial enzymes pose an allergy risk that cannot be neglected. To reduce exposure to enzymes effectively, less dusty preparations, such as granules or oil suspensions, will eventually have to be introduced. Follow up studies of the exposed populations and monitoring of enzyme exposure are needed to estimate whether these actions are sufficient to prevent sensitisation. Immediate precautions are needed to decrease the exposure of workers, for example through the use of exhaust hoods and local ventilation systems especially in the dusty phases, like the weighing processes, and on the dough pots. ${ }^{17}$ This is a commendable measure for bakeries regardless of the use of enzymes.

The problems of establishing hygienic limit values for industrial enzymes remain; the only present limit value is for subtilisin proteases. ${ }^{35}$ For $\alpha$-amylase, it has been estimated that sensitisation and respiratory symptoms have been caused by concentrations of $0 \cdot 2-30 \mu \mathrm{g} / \mathrm{m} .^{323}$ Our results support this, but further studies measuring enzyme concentrations by stan- 
dardised methods are needed to establish hygienic limit values for $\alpha$-amylases and cellulases.

We acknowledge the help of Mr Reima Kämppi for dust sampling, and Ms Riitta Valio and Ms Terttu Mäkelä for allergy testing. We are grateful to Ms Ulla Tiikkainen for her advice on the flour extracts. The work was supported by grants from the Finnish Work Environment Fund.

1 Flindt MLH. Pulmonary disease due to inhalation of derivatives of bacillus subtilis containing proteolytic enzymes. Lancet 1969; i:1177-81.

2 Gilson TL, Juniper CP, Martin RB, Weill H. Biological effects of proteolytic enzymes. Thorax 1976;31:621-34.

3 Baur X, Fruhmann G. Papain-induced asthma: diagnosis by skin test, RAST and bronchial provocation test. Clin Allergy 1979;9:75-81.

4 Losada E, Hijonosa M, Quirce S, Sanchez-Cano M Moneo I. Occupational asthma caused by alpha-amylase inhalation: clinical and immunological findings and bronchial response patterns. $\mathcal{F}$ Allergy Clin Immunol 1992; 89:118-25.

5 Tarvainen $K$, Kanerva L, Tupasela $O$, Grenguist-Nordén $B$, Jolanki R, Estlander T, Keskinen H. Allergy from cellulase and xylanase enzymes. Clin Exp Allergy 1991;21: 609-15.

6 Baur X, Fruhmann G, Haug B, et al. Role of Aspergillus amylase in bakers' asthma. Lancet 1986;i:43.

7 Baur X, Sauer W, Weiss W. Baking additives as new allergens in baker' asthma. Respiration 1988;54:70-2.

8 Brisman J, Belin L. Clinical and immunological responses to occupational exposure to alpha-amylase in the baking industry. $\mathrm{Br} \mathcal{F}$ Ind Med 1991;48:604-8.

9 Carmona BJG, Picon JS, Sotilles GM. Occupational asthma in bakeries caused by sensitivity to $\alpha$-amylase. Allergy 1991;46:274-6.

10 Morren AM, Janssens V, Dooms-Goossens A, Pharm R, Van Hoeyveld E, Cornelis A, et al. Amylase, a flour additive: an important cause of protein contact dermatitis in bakers. 7 Am Acad Dermatol 1993;29:723-8.

11 Quirce S, Cuevas M, Luz Diez-Gomez M, FernandezRivas M, Hijonosa M, Gonzales R, Losada E. Respiratory allergy to Aspergillus-derived enzymes in Respiratory allergy to Aspergillus-derived enzymes in
bakers' asthma. F Allergy Clin Immunol 1992;90:970-8.

12 De Zotti R, Larese F, Bovenzi M, Negro C, Molinari S. Allergic airway disease in Italian bakers and pastry makers. Occup Environ Med 1994;51:548-52.

13 Cullinan P, Lowson D, Nieuwenhuijsen MJ, Sandiford C, Tee RD, Venables KM, et al. Work related symptoms, sensitisation, and estimated exposure in workers not previously exposed to flour. Occup Environ Med 1994;51: 579-83.

14 Agarwall MK, Ingram JW, Dunnette S, Gleicch GJ Immunochemical quantitation of an airborne proteolytic enzyme, Esperase, in a consume

15 Liss GM, Kominsky JR, Gallagher JS, Melius J, Brooks SM, Bernstein IL. Failure of enzyme encapsulation to prevent sensitization of workers in the dry bleach industry. F Allergy Clin Immunol 1984;73:348-55.

16 Juniper CP, How MJ, Goodwin BFJ, Kinshott AK Bacillus subtilis enzymes: a 7-year clinical, epidemiological and immunological study of an industrial allergen. $f$ Occup Med 1977;27:3-12.

17 Jauhiainen A, Louhelainen K, Linnainmaa M. Exposure to dust and $\alpha$-amylase in bakeries. Appl Occup Environ $H y g$ 1993;8:721-5.

18 Burdorf A, Lillienberg L, Brisman J. Characterization of exposure to inhalable flour dust in Swedish bakeries. Ann Occup Hyg 1994;38:67-78.

19 Belin L, Holmyr B, Ståhl A. Assays for airborne fungal $\alpha$ amylase in food and baking industries. XV International annual meeting of the European Academy of Allergology and Clinical Immunology. Stockholm: Hogrefe and Huber, 1994:49.

20 Björksten F, Backman A, Järvinen KAJ, Lenti H, Savilanti E, Syvänen $\mathrm{P}$, et al. Immunoglobulin E specific to wheat and rye flour proteins. Clin Allergy 1977;7:473-83.

21 Kanerva L, Estlander T, Jolanki R. Skin testing for immediate hypersensitivity in occupational allergology. In Menne T, Maibach HI, ronmental dermatitis. Boca Raton, Florida: CRC Press, 1991:103-26.

22 Ceska M, Eriksson R, Varga JM. Radioimmunosorbent assay of allergens. $\mathcal{F}$ Allergy Clin Immunol 1972;49:1-9.

23 Brisman J. Industrial enzymes. The Nordic Expert Group for Criteria Documentation of Health Risks from Chemicals. Arbete och Hälsa 1994:28:1-25.

24 Hawkes R, Niday E, Gordon J. A Dot-immunobinding assay for monoclonal and other antibodies. Anal Biochem 1982;199:142-7.

25 Harkki A, Mäntylä A, Penttilä M, Muttilainen S, Buhler R, Suominen P, Knowles J, Nevalainen $\mathrm{H}$. Genetic engineering of Trichoderma to produce strains with novel cellulase profiles. Enzyme Microbiology and Technology cellulase profiles.

26 Törrönen A, Mach RL, Messner R, Gonzalez R, Kalkkinen N, Harkki A, Kubicek CP. The two major xylanases from Trichoderma reesei: characterization of both enzymes and genes. Biotechnology 1992;10:1461-5.

27 Musk AW, Venables KM, Crook B, Nunn AJ, Hawkins R, Crook GDW, et al. Respiratory symptoms, lung function, and sensitisation to flour in a British bakery. BrF Ind Med 1989;46:636-42.

28 Nieuwenhuijsen MJ, Sandiford CP, Lowson D, Tee RT, Venables KM, McDonald JC, Newman Taylor AJ. Dust and flour aeroallergen exposure in flour mills and bakand flour aeroallergen exposure in flour

29 Sandiford CP, Tee RT, Newman Taylor AJ. The role of cereal and fungal amylases in cereal flour hypersensitivity. Clin Exp Allergy 1994;24:549-57.

30 Moneo I, Alday E, Gonzales-Muñoz M, Maqueda J, Curiel $G$, Lucena $R$. Amylase hypersensitivity in non-exposed millers. Occup Med 1994;44:91-4.

31 Prichard MG, Ryan G, Wash BJ, Musk AW. Skin test and RAST responses to wheat and common allergens and respiratory disease in bakers. Clin Allergy 1985;15: 203-10.

32 van Hage-Hamsten $M$, Johansson SGO, Höglund S, Tüll $P$, Wirén $A$, Zetterström $O$. Storage mite allergy is common in a fetterstrom . Storage mite allergy is common in

33 van Hage-Hamsten M. Allergens of storage mites. Clin Exp Allergy 1992;22:429-31.

34 Nordman H. Occupational asthma-time for prevention Scand f Work Environ Health 1994;20:108-15.

35 American Conference of Governmental Industrial Hygienists. Documentation of threshold limit values, 4 th ed. Cincinnati, Ohio: ACGIH, 1980. 